\title{
DUPLEX POLYMERASE CHAIN REACTION UNTUK DETEKSI SIMULTAN KOI HERPESVIRUS DAN Aeromonas hydrophila PADA IKAN MAS (Cyprinus carpio)
}

\author{
Hessy Novita, Tuti Sumiati, Desy Sugiani, dan Taukhid \\ Instalasi Riset Pengendalian Penyakit Ikan \\ Balai Riset Perikanan Budidaya Air Tawar dan Penyuluhan Perikanan \\ Jl. Sempur No. 1, Bogor 16154 \\ (Naskah diterima: 16 September 2019; Revisi final: 10 Februari 2020; Disetujui publikasi: 10 Februari 2020)
}

\begin{abstract}
ABSTRAK
Koi herpesvirus (KHV) dan Aeromonas hydrophila adalah patogen yang dapat mengkoinfeksi ikan mas secara bersamaan. Penelitian ini bertujuan untuk mengembangkan metode duplex polymerase chain reaction (dPCR), deteksi simultan untuk diagnosis KHV dan bakteri Aeromonas hydrophila pada ikan mas. Dua pasang primer yang menargetkan sekuen spesifik Sphl dan gen aerolisin, yang sering digunakan untuk mendeteksi KHV dan A. hydrophila dalam uji reaksi tunggal PCR dan menghasilkan target pita PCR 290 bp dan 417 bp. Hasil penelitian menunjukkan bahwa metode duplex PCR dapat mendeteksi ganda infeksi KHV dan A. hydrophila pada ikan mas dan metode ini lebih efektif mendeteksi dua patogen secara bersamaan dalam satu reaksi PCR pada suhu pradenaturasi, $94^{\circ} \mathrm{C}$ selama dua menit, denaturasi pada suhu $95^{\circ} \mathrm{C}$ selama satu menit, annealing pada suhu, $55^{\circ} \mathrm{C}$ selama satu menit, dan $72^{\circ} \mathrm{C}$ selama satu menit, dengan 30 siklus amplifikasi dan final extention pada suhu $72^{\circ} \mathrm{C}$ selama lima menit. Metode dPCR untuk deteksi simultan kedua patogen adalah salah satu metode yang dapat diaplikasikan untuk deteksi koinfeksi virus dan bakteri dalam satu reaksi PCR.
\end{abstract}

KATA KUNCl: pathogen; duplex PCR, KHV; Aeromonas hydrophila; Sphl; gen aerolisin

ABSTRACT: Duplex PCR for simultaneous detection of koi herpesvirus (KHV) and Aeromonas hydrophila in common carp (Cyprinus carpio). By: Hessy Novita, Tuti Sumiati, Desy Sugiani, and Taukhid

\begin{abstract}
Koi herpesvirus (KHV) and Aeromonas hydrophila are pathogens that can co-infect common carp. This study aimed to develop a duplex polymerasechain reaction (dPCR) method to detect KHV and Aeromonas hydrophila in common carp simultaneously. Two pairs of primers targeted the specific sequences of Sphl and aerolysin genes, often used in detecting KHV and A. hydrophila, in a single PCR reaction test and produced target bands of PCR $290 \mathrm{bp}$ and $417 \mathrm{bp}$. This proposed method was more effective in simultaneously detecting the two pathogens in one PCR reaction at prenaturation temperature of $94^{\circ} \mathrm{C}$ for two minutes, denaturation at $95^{\circ} \mathrm{C}$ for one minute, annealing at temperature, $55^{\circ} \mathrm{C}$ for one minute, and $72^{\circ} \mathrm{C}$ for one minute, with 30 cycles of amplification and final extension at $72^{\circ} \mathrm{C}$ for five minutes. The findings showed that the duplex PCR method could be used to double detect KHV and $\mathbf{A}$. hydrophila infection in common carp. The duplex PCR method for simultaneous detection of both pathogens is one method that can be applied for the detection of co-infection of viruses and bacteria in a PCR reaction.
\end{abstract}

KEYWORDS: pathogen; duplex PCR; KHV; Aeromonas hydrophila; Sphl; aerolisyn gene

\section{PENDAHULUAN}

Koi herpesvirus (KHV) atau saat ini lebih tepat disebut sebagai Cyprinid herpes virus-3 (CyHV-3) telah menimbulkan kerugian besar pada budidaya ikan mas (Cyprinus carpio) dan ikan koi (Cyprinus carpio koi) di seluruh dunia dengan penularan yang sangat cepat dan

\footnotetext{
\# Korespondensi: Balai Riset Perikanan Budidaya Air Tawar dan Penyuluhan Perikanan. Jl. Sempur No. 1, Bogor 16154, Indonesia

Tel. + 622518313200

E-mail: hestahamdani@gmail.com
}

virulensi yang tinggi sehingga menyebabkan wabah penyakit dengan mortalitas tinggi (Ronen et al., 2003). KHV dapat menyebabkan kematian massal dengan mortalitas $80 \% 95 \%$ dari ikan mas dan koi yang dibudidayakan sehingga menyebabkan kerugian ekonomi yang tinggi hampir di seluruh dunia antara lain di Jepang, USA, Israel, negara-negara di Eropa, Afrika, dan Indonesia. Kerugian yang sangat besar pada industri akuakultur ini dapat terjadi dikarenakan ikan mas dan koi merupakan komoditas utama ikan konsumsi dan ikan hias. 
Di Indonesia, penyebaran penyakit ini telah terjangkit hampir semua daerah yang membudidayakan ikan mas. Budidaya ikan secara intensif, pameran ikan koi dan perdagangan di dalam dan luar negeri tanpa peraturan dan pembatasan yang tegas dalam pemeriksaan dan penerapan program karantina merupakan penyebab cepatnya penyebaran penyakit ini secara global (Gilad et al., 2003; Pikarsky et al., 2004). Penyakit virus ini muncul pada saat suhu air berkisar antara $18^{\circ} \mathrm{C}-28^{\circ} \mathrm{C}$ atau pada permissive temperature (Gilad et al., 2003; Perelberg et al., 2003). Pada umumnya gejala klinis ikan mas yang terinfeksi KHV berupa kerusakan (nekrosis) parah pada insang. Kematian pada ikan yang terinfeksi teramati mulai terjadi pada hari ketujuh setelah infeksi dan kematian dapat terus terjadi hingga mencapai mortalitas di atas 90\%dalam waktu 2-3 minggu (Hedrick et al., 2000).

Infeksi KHV biasanya diikuti oleh adanya koinfeksi bakteri berupa luka atau bercak merah di permukaan tubuh yang disebabkan oleh bakteri seperti Aeromonas hydrophila (Ye et al., 2013). Bakteri Aeromonas hydrophila merupakan salah satu bakteri patogen yang membahayakan bagi budidaya perikanan air tawar karena dapat menginfeksi semua stadia. Bakteri A. hydrophila menyebabkan penyakit motile aeromonas septicemia (MAS) atau penyakit bercak merah dengan gejala klinis berupa luka di bagian tubuh ikan dan bercak merah pada bagian tubuh. Infeksi bakteri A. hydrophila dapat terjadi akibat perubahan kondisi lingkungan, stres, perubahan suhu, dan ketika inang tersebut telah terinfeksi oleh virus, bakteri atau parasit lainnya (infeksi sekunder), oleh karena itu bakteri ini disebut dengan bakteri yang bersifat patogen oportunistik (Dooley et al., 1985).

Virus KHV yang menginfeksi ikan mas secara bersamaan dengan $\mathrm{A}$. hydrophila sering ditemukan bila dilakukan deteksi secara tunggal dengan PCR. Dari masalah tersebut perlu dilakukan penelitian untuk dapat mendeteksi virus KHV dan A. hydrophila atau double infeksi dengan metode duplex PCR. Metode duplex PCR (dPCR) merupakan modifikasi dari PCR yang memungkinkan amplifikasi secara simultan dengan dua pasang primer untuk mengamplifikasi template DNA dalam satu reaksi tunggal untuk target yang berbeda. Teknik ini digunakan untuk diagnosis penyakit yang berbeda dalam sampel yang sama (Belàk et al., 2009). Metode duplex PCR lebih efisien, hemat waktu, dan biayajika dibandingkan dengan singlePCR atau uniplex PCR. Beberapa peneliti telah menggunakan teknik dPCR untuk deteksi patogen, Yasmon et al. (2010) telah mendeteksi secara simultan Legionella species dan Legionella pneumophila dengan dPCR pada sampel air di Jakarta. Thanananta \& Thanananta (2008) mendeteksi E. coli yang berasal dari air menggunakan
dPCR dengan target gen lacZ dan uidA. Penelitian ini bertujuan untuk mengembangkan deteksi simultan virus KHV dan bakteri A. hydrophila dalam satu reaksi $P C R$, sehingga nantinya metode ini dapat menjadi metode yang lebih efektif dan efisein dalam proses deteksi kedua patogen ini.

\section{BAHAN DAN METODE}

\section{Tahap Persiapan}

Sampling sampel ikan mas sakit dari sentra budidaya ikan mas yaitu dari daerah Sukabumi, Danau Maninjau, dan sampel koleksi IRP2I, untuk isolasi DNA virus KHV dan bakteri A. hydrophila, perbanyakan dsDNA dengan metode PCR menggunakan spesifik primer dengan reaksi tunggal PCR dan duplex PCR.

\section{Ektraksi DNA KHV dan Bakteri A. hydrophila}

DNA bakteri $A$. hydrohila dikultur pada media trypticase soy broth (TSB) kemudian digores ke media trypticase soy agar (TSA) dan inkubasi pada $28^{\circ} \mathrm{C}$ selama 18 jam, selanjutnya bakteri diekstraksi dengan metode perebusan. Satu lup koloni diencerkan dengan $\mathrm{ddH}_{2} \mathrm{O} 500 \mu \mathrm{L}$ dan diinkubasi pada suhu $100^{\circ} \mathrm{C}$. Suspensi sel kemudian disentrifuse pada $10,000 \times \mathrm{g}$ selama 10 menit pada suhu $4^{\circ} \mathrm{C}$. Supernatan dibuang dan pellet dilarutkan dengan $50 \mathrm{iL} \mathrm{ddH_{2 }} \mathrm{O}$, kemudian diukur konsentrasi dan kemurnian DNA yang diperoleh dengan nannodrop, dan disimpan pada suhu $20^{\circ} \mathrm{C}$ sampai DNA digunakan sebagai template PCR.

Ekstraksi DNA KHV dari jaringan yang terinfeksi KHV menggunakan (gSYNC DNA extraction kit quick genoaid kit: geneaid) dilakukan dengan menggunakan petunjuk ekstraksi DNA mengikuti prosedur yang tertulis dalam protokol dari kemasan kit. Sampel jaringan insang sebanyak $25 \mathrm{mg}$ digerus sampai hancur menggunakan pestle lalu dimasukkan ke dalam tabung mikro 1,5 mL. Hasil gerusan ditambahkan $200 \mu \mathrm{L}$ GST Buffer dan $20 \mu$ L proteinase $\mathrm{K}$, di-vortex dan selanjutnya mengikuti protokol yang telah tersedia pada kemasan kit. Hasil ekstraksi DNA kemudian disimpan dalam freezer $-20^{\circ} \mathrm{C}$ sebelum diamplifikasi dengan mesin PCR.

\section{Single PCR}

DNA KHV dan bakteri A. hydrophila dari sampel ikan mas yang telah diekstraksi kemudian masingmasing diamplifikasi dengan PCR. Komposisi larutan PCR untuk deteksi KHV dan A. hydrophila pada $25 \mu \mathrm{L} /$ reaksi dengan mencampurkan master mix $12,5 \mu \mathrm{L}$ (promega); nuclease free water $8,5 \mu \mathrm{L}$; primer $10 \mathrm{pmol}$ untuk forward $1 \mu \mathrm{L}$; reverse $1 \mu \mathrm{L}$; dan template DNA 2 $\mu \mathrm{L}$. Proses amplifikasi menggunakan masing-masing dua pasang primer yang spesifik untuk KHV dan A. hydrophila. Untuk mendeteksi KHV menggunakan 
primer KHV yang dimodifikasi oleh Yuasa et al. (2005) dan standar OIE (2016), sedangkan primer yang untuk deteksi A. hydrophila berdasarkan rujukan literature (Nam \& Joh, 2007) yang telah dimodifikasi, urutan primer, dan ukuran produk amplifikasinya dapat dilihat pada Tabel 1.

\section{Optimasi Duplex PCR (dPCR)}

Optimasi dPCR untuk simultan deteksi KHV dan A. hydrophila dalam reaksi PCR dilakukan berdasarkan Tabel 2. diketahui suhu setiap primer berbeda-beda sedangkan prinsip kerja dPCR yaitu menggunakan dua pasang primer dalam satu kali running PCR dengan suhu PCR yang sama. Oleh karena itu, perlu dilakukan optimasi kondisi suhu PCR terlebih dahulu. Optimasi awal dilakukan dengan menggunakan uniplex PCR untuk menentukan suhu annealing optimum masing-masing primer kemudian dilanjutkan dengan optimasi dPCR. Kisaran gradien suhu yang digunakan dalam optimasi suhu annealing kedua pasangan primer adalah $55^{\circ} \mathrm{C}$; $56^{\circ} \mathrm{C} ; 60^{\circ} \mathrm{C}$; $63^{\circ} \mathrm{C}$; dan $67^{\circ} \mathrm{C}$ dengan reaksi PCR 30 siklus, 35 siklus, dan 40 siklus. Hasil optimasi suhu pada single kemudian digunakan dalam dPCR, faktor lain yang diperhatikan dalam dPCR adalah optimasi konsentrasi master mix dan primer. Komposisi dPCR untuk membuat campuran menggunakan master mix KAPA $2 \mathrm{G}$ fast multiplex dapat dilihat pada Tabel 3.

\section{Running Elektroforesis}

Agarose ditimbang 1,5\% kemudian dilarutkan dalam $100 \mathrm{~mL}$ TAE satu kali, agarose dipanaskan sampai mendidih dengan microwave, larutan agar didinginkan hingga suhu $60^{\circ} \mathrm{C}$ selama kurang lebih 15 menit, kemudian dicetak dalam tray agarose yang telah dilengkapi dengan sisir untuk membentuk sumursumur gel. Gel didiamkan sampai mengeras (30-45 menit). Setelah mengeras, gel diambil dan diletakkan ke dalam bak elektroforesis yang berisi buffer TAE satu kali. Amplicon PCR sebanyak $10 \mu \mathrm{L}$ diberi loading dye sebanyak $2 \mu \mathrm{L}$, di-running dalam gel elektroforesis bersama-sama dengan $5 \mu \mathrm{L}$ DNA marker 100 bp. Setelah semua hasil PCR diinjeksikan ke dalam sumur-sumur gel elektroforesis, selanjutnya elektroforesis dijalankan dengan tegangan 100 volt, selama 25 menit.

\section{Visualisasi Hasil Amplifikasi}

Gel hasil elektroforesis direndam dalam larutan ethidium bromida (konsentrasi $10 \mu / 100 \mathrm{~mL}$ aquadest) selama 15 menit. Selanjutnya gel dibilas dengan aquadest selama 10 menit. Gel hasil elektroforesis diamati menggunakan geldoc yang sekaligus dilakukan pengambilan foto untuk dokumentasi dengan kamera digital dengan target pita PCR 417 bp untuk A. hydrophila dan KHV pada taget pita PCR 290 bp.

\section{Limit of Detection (LOD) dPCR KHV dan A. hydrophila}

LOD (limit of detection) dari dPCR DNA KHV dan A. hydrophila adalah melakukan pengenceran serial DNA dengan konsentrasi yang digunakan untuk pengujian adalah $100 \mathrm{ng} / \mathrm{mL}, 10 \mathrm{ng} / \mathrm{mL}, 1 \mathrm{ng} / \mathrm{ml}, 100 \mathrm{pg} / \mathrm{mL}, 10$

Tabel 1. Reaksi PCR dan primer untuk mendeteksi KHV (OIE, 2016; Yuasa et al., 2005) dan A. hydrophila (Nam \& Joh, 2007)

Table 1. PCR reactions and primer for detecting KHV (OIE, 2016; Yuasa et al., 2005) and A. hydrophila (Nam \& Joh, 2007)

\begin{tabular}{|c|c|c|c|c|}
\hline \multicolumn{2}{|c|}{$\begin{array}{c}\text { Sekuen Primer (5' ke 3',) dan suhu PCR } \\
\text { Primer sequence (5 to } 3^{\prime}, \text { ) and PCR temperature }\end{array}$} & $\begin{array}{l}\text { Target gen } \\
\text { Gene target }\end{array}$ & $\begin{array}{l}\text { Target spesifik } \\
\text { Specific target }\end{array}$ & $\begin{array}{c}\text { Produk PCR } \\
\text { PCR product (bp) }\end{array}$ \\
\hline \multicolumn{5}{|c|}{ F-5'GAC ACC ACA TCT GCA AGG AG3' } \\
\hline \multicolumn{5}{|c|}{ R-5'GAC ACA TGT TAC AAT GGT CGC-3" } \\
\hline Pradenaturasi (Predenaturation) & : $94^{\circ} \mathrm{C} ; 30$ detik (seconds) & \multirow{6}{*}{ Sphl } & \multirow{6}{*}{ KHV } & \multirow{6}{*}{290} \\
\hline Denaturasi (Denaturation ) & $94^{\circ} \mathrm{C} ; 30$ detik (seconds) & & & \\
\hline Annealing & $63^{\circ} \mathrm{C} ; 30$ detik (seconds) & & & \\
\hline Extention & $72^{\circ} \mathrm{C} ; 30$ detik (seconds) & & & \\
\hline Final-extention & $: 72^{\circ} \mathrm{C} ; 7$ menit (minute) & & & \\
\hline Jumlah siklus (Number of cycles) & : 40 siklus (cycle) & & & \\
\hline \multicolumn{2}{|c|}{ F; 5'-GAG CGA GAA GGT GAC CAC CAA GAA C-3' } & \multirow{5}{*}{ Aerolisin } & \multirow{5}{*}{ A. hydrophila } & \multirow{5}{*}{417} \\
\hline \multicolumn{5}{|c|}{$\begin{array}{l}\mathrm{R} ; 5^{\prime}-\mathrm{TTC} \text { CAG TCC CAC CAC TTC ACT TCA C-3' } \\
\text { Pradenaturasi (Predenaturation) : }: 94^{\circ} \mathrm{C} ; 2 \text { menit (minute) }\end{array}$} \\
\hline Denaturasi (Denaturation ) & $: 94^{\circ} \mathrm{C} ; 1$ menit (minute) & & & \\
\hline Extention & $72^{\circ} \mathrm{C} ; 45$ detik (seconds) & & & \\
\hline Final-extention & $72^{\circ} \mathrm{C} ; 5$ menit (minute) & & & \\
\hline Jumlah siklus (Number of cycles) & : 30 siklus (cycle) & & & \\
\hline
\end{tabular}


Tabel 2. Optimasi suhu dPCR berdasarkan modifikasi pada suhu annealing single PCR

Table 2. Optimization of dPCR temperature based on modification of a single PCR annealing temperature

\begin{tabular}{lc}
\hline Tahapan PCR (PCR step) & Suhu PCR (PCR temperature) \\
\hline Pradenaturasi & $94^{\circ} \mathrm{C}$ selama $2-5$ menit $\left(94^{\circ} \mathrm{C}\right.$ for $2-5$ minute) \\
\hline Denaturasi & $95^{\circ} \mathrm{C}$ selama 1 menit $\left(95^{\circ} \mathrm{C}\right.$ for 1 minute) \\
Denaturation & $55^{\circ} \mathrm{C}$ \\
& $56^{\circ} \mathrm{C}$ \\
\hline & $60^{\circ} \mathrm{C}$ \\
Annealing & $63^{\circ} \mathrm{C}$ \\
& $67^{\circ} \mathrm{C}$ \\
& \\
\hline Extention & Selama 30 detik; satu menit (For 30 seconds; one minute) \\
Final Extention & $72^{\circ} \mathrm{C}$ selama 30 detik; satu menit $\left(72^{\circ} \mathrm{C}\right.$ for 30 seconds; one minute) \\
Siklus (Cycle) & $72^{\circ} \mathrm{C}$ selama lima menit $\left(72^{\circ} \mathrm{C}\right.$ for five minute) \\
\hline
\end{tabular}

Tabel 3. Optimasi konsentrasi mastermix KAPA2G Fast Multiplex berdasarkan modifikasi dari manual dari kit

Table 3. The concentration optimization of KAPA2G Fast Multiplexmastermix modified from the kit manual

\begin{tabular}{lc}
\hline \multicolumn{1}{c}{ Larutan PCR (PCR mix) } & Jumlah (Amount) $(\mu \mathrm{L})$ \\
\hline Buffer & 12.5 \\
F/R primer KHV (10 pmol) & $1 ; 1.5$ \\
F/R primer aerolisin (10 pmol) & $1 ; 1.5$ \\
DNA KHV & 2 \\
DNA A. hydrophila & 2 \\
Nuclease free water & $6.5 ; 5.5$ \\
\hline
\end{tabular}

$\mathrm{pg} / \mathrm{mL}, 1 \mathrm{pg} / \mathrm{mL} .100 \mathrm{fg} / \mathrm{mL}, 10 \mathrm{fg} / \mathrm{mL}, 1 \mathrm{fg} / \mathrm{mL}$, dan 100 $\mathrm{Ag} / \mathrm{mL}$. Pengenceran dilakukan dengan menambahkan $\mathrm{dd}_{2} \mathrm{O}$ dan diamplifikasi menggunakan $\mathrm{dPCR}$, selanjutnya dielektroforesis dan dokumentasi. Kode sampel untuk menghitung LOD adalah KHV2 dan AH.

\section{HASIL DAN BAHASAN}

Isolasi KHV dan A. hydrophila dari jaringan ikan mas diperoleh dari daerah budidaya ikan mas yaitu Sukabumi, Danau Maninjau, dan isolat koleksi Laboratorium Instalasi Riset Pengendalian Penyakit Ikan (IRP2I). Ikan mas yang diisolasi kedua patogen tersebut tidak semuanya menunjukkan terinfeksi oleh ko-infeksi KHV dan A. hydrophila yang bisa dilihat dari Tabel 4.

Gejala ikan yang terinfeksi ko-infeksi KHV dan A. hydrophila adalah pada insang ditemukan bercak putih, geripis di pinggir insang, adanya luka, dan pembengkakan di hati dan ginjal (Gambar 1). Biasanya kondisi ini diikuti dengan infeksi sekunder bakterial seperti kulit melepuh maupun luka borok di permukaan tubuh, kadang-kadang disertai pendarahan pada sirip/badan. Koleksi sampel isolat tersebut dipreparasi dengan identifikasi uji PCR. Pada uji PCR menggunakan metode single PCR dan dilanjutkan dengan pengujian deteksi duplex PCR.

\section{Single PCR}

Hasi deteksi singlePCR, DNA KHV dan A. hydrophila dari jaringan yang terinfeksi menunjukkan hasil PCR positif KHV dan A. hydrophila, pada pita DNA 290 bp. Sedangkan A. hydrophila terdeteksi pada pita DNA 417 bp. Hasil PCR pada kedua patogen yang menginfeksi ikan mas, memperlihatkan bahwa masing-masing patogen dapat dideteksi secara tunggal dengan menggunakan PCR. Sehingga dapat dikembangkan untuk uji dPCR, dengan optimasi suhu PCR, terutama 
Tabel 4. Hasil skrining isolat KHV dan A. hydrophila dari daerah Sukabumi, Danau Maninjau, dan IRP2I

Table 4. Screening results of KHV and $\mathbf{A}$. hydrophila isolates from Sukabumi, Maninjau Lake, and IRP2I

\begin{tabular}{lll}
\hline \multicolumn{1}{c}{ Asal daerah (Origin) } & Koi Herpes Virus (KHV) & Aeromonas hydrophila \\
\hline Sukabumi & Dua isolat (Two isolate) & Satu isolat (One isolate) \\
Danau Maninjau (Lake Maninjau) & Dua isolat (Two isolate) & - \\
IRP2I & Satu isolat (One isolate) & Satu isolat (One isolate) \\
\hline
\end{tabular}

untuk masing-masing suhu annealing pada kedua patogen baik KHV dan A. hydrophila yaitu pada rentang suhu $63^{\circ} \mathrm{C}$ dan $56^{\circ} \mathrm{C}$. Sampel ikan yang terdeteksi positif ko-infeksi KHV dan A. hydrophila digunakan sebagai sampel untuk uji optimasi duplex PCR yang bisa dilihat pada Gambar 4 dan 5.
Pada pengujian deteksi KHV dan A. hydrophila telah diketahui konsentrasi dan kemurnian dengan nanodrop yang bisa dilihat pada Tabel 5. Nilai kemurnian DNA dapat ditentukan dengan besarnya nilai rasio absorbansi $A_{260 / 280}$. Hasil pengukuran nilai kemurnian DNA sampel ikan mas yang terkena KHV (Tabel 4.)

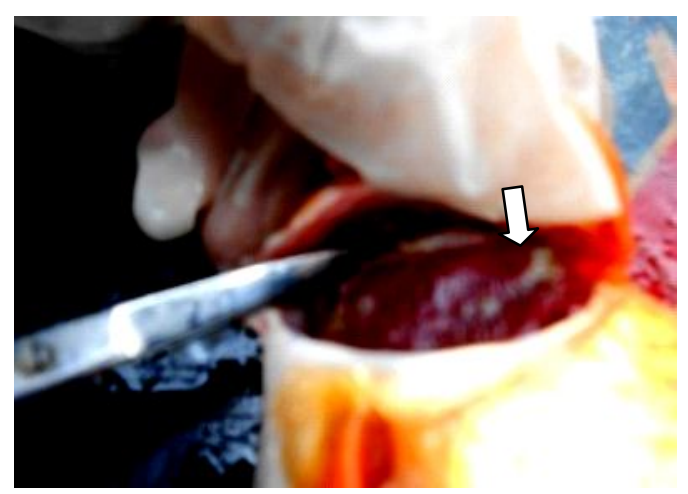

Gambar 1. Koleksi sample jaringan insang dari ikan yang terinfeksi KHV (tanda infeksi ditunjukkan dengan bercak putih pada insang).

Figure 1. Collection of gills' samples from KHV-infected common carp (sign of infection is shown by the appearance of white patches on the gills).

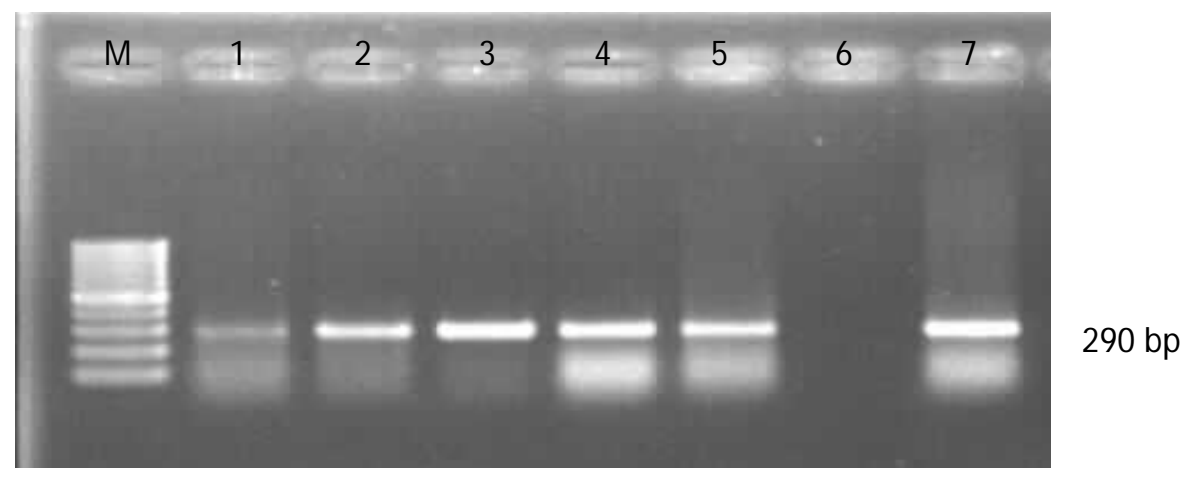

Gambar 2. Deteksi KHV dengan single PCR, dengan target pita DNA KHV pada 290 bp. M; marker 100 bp, (1) sampel Sukabumi-1, (2) sampel Sukabumi-2, (3) sampel Danau Maninjau-1, (4) sampel Danau Maninjau-2, (5) sampel IRP2I, (6) kontrol negatif, (7) ) kontrol positif.

Figure 2. Detection of KHV with a single PCR, targeting the DNA KHV band at $290 \mathrm{bp} . \mathrm{M}$ : marker $100 \mathrm{bp}$, (1) Sukabumi sample-1, (2) Sukabumi sample-2, (3) Maninjau Lake sample-1, (4) Maninjau Lake sample-2, (5) IRP2I sample, (6) negative control, (7) positive control 


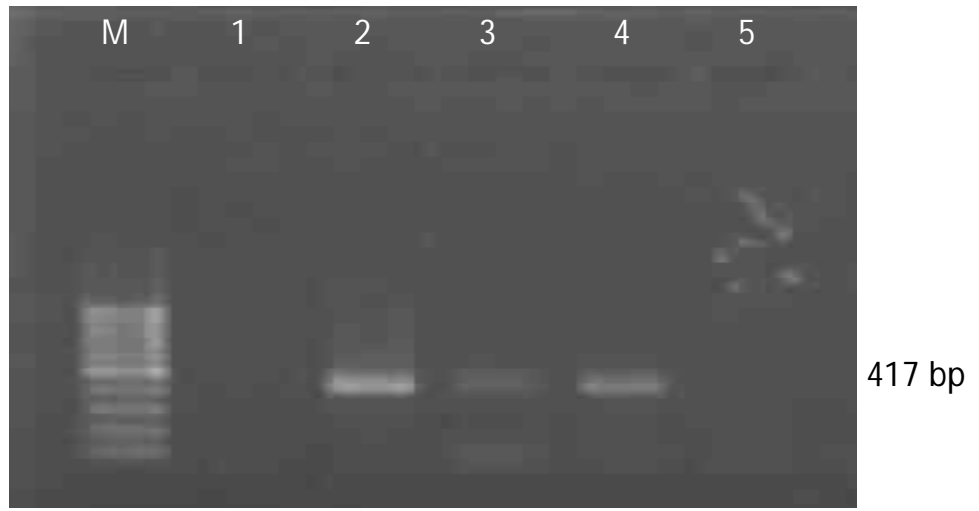

Gambar 3. Deteksi A. hydrophila dengan single PCR, dengan target pita DNA pada 417 bp. M: marker $100 \mathrm{bp},(1)$ kontrol negatif, (2) kontrol positif, (3) sampel Sukabumi, (4) sampel IRP2I, (5) sampel Danau Maninjau-1.

Figure 3. Detection of $\mathbf{A}$. hydrophila with a single PCR, targeting the DNA KHV band at 417 bp. M: marker 100 bp, (1) negative control, (2) positive control, (3) Sukabumi sample, (4) IRP2I sample, (5), Maninjau Lake-1 sample.

memberikan hasil berkisar antara 1,84-1,96 dan konsentrasi DNA-nya berkisar 99,5-197,6 ng/mL. Sedangkan untuk hasil pengukuran nilai kemurnian DNA A. hydrophila (Tabel 4) memberikan hasil berkisar antara 1,90-2,20 dan konsentrasi DNA nya berkisar 137,1-295,6 ng/mL. Menurut Sambrook et al. (2001), hasil isolasi DNA dikatakan murni jika nilai rasio antara $1,8-2,0$.

\section{Optimasi Duplex PCR}

Optimasi dilakukan untuk mendapatkan reaksi duplex PCR yang paling optimum dengan melakukan single PCR pada tahap awal. Adapun optimasi yang dilakukan meliputi konsentrasi master mix yang dipakai, suhu annealing, dan waktu/lama extention. Optimasi PCR dengan reaksi amplifikasi menggunakan dua pasang primer dengan variasi suhu annealing, agar mendapatkan kondisi PCR yang optimal dan menghasilkan produk PCR spesifik atau terbentuk pita DNA dengan ukuran yang sesuai. Tidak terbentuk dimer primer, smear atau multi band, dan yang terpenting untuk mencari suhu annealing yang tepat agar semua primer dapat bekerja. Suhu optimal annealing untuk duplex PCR KHV dan A. hydrophila ditentukan dengan pemeriksaan visual dengan hasil pita DNA pada gel agarose. Suhu optimal annealing didefinisikan sebagai suhu annealing yang menghasilkan produk PCR spesifik tertinggi sesuai dengan target pita DNA KHV dan A. hydrophila. Pada suhu annealing $60^{\circ} \mathrm{C}$ dan $63^{\circ} \mathrm{C}$, intensitas pita $290 \mathrm{bp}$ DNA KHV masih terdeteksi dan DNA A. hydrophila pada 417 bp menunjukkan pita DNA negatif, dan pada suhu annealing dari $67^{\circ} \mathrm{C}$ kedua gen target negatif (Gambar 4). Sedangkan DNA KHV dan A. hydrophila, pita DNA spesifik menunjukkan DNA positif terdeteksi pada suhu annealing dari suhu $55^{\circ} \mathrm{C}$ dan $56^{\circ} \mathrm{C}$.

Tabel 5. Hasil pengukuran konsentrasi DNA isolat KHV dan A. hydrophila dari ikan mas

Table 5. The results of measurement of KHV and $\mathbf{A}$. hydrophila DNA isolate concentrations from common carp

\begin{tabular}{ccc}
\hline $\begin{array}{c}\text { Isolat } \\
\text { Isolate }\end{array}$ & $\begin{array}{c}\text { Konsentrasi DNA } \\
\text { DNA concentration }(\mathbf{n g} / \mathbf{m L})\end{array}$ & $\begin{array}{c}\text { Kemurnian DNA } \\
\text { DNA purity (280/260) }\end{array}$ \\
\hline KHV-1 & 99.5 & 1.85 \\
KHV-2 & 130.8 & 1.88 \\
KHV-3 & 98.2 & 1.96 \\
KHV-4 & 97.3 & 1.83 \\
KHV-5 & 197.6 & 1.84 \\
AH-1 & 295.6 & 1.86 \\
AH-2 & 206.9 & 2.20 \\
\hline
\end{tabular}


Suhu annealing optimal dari primer yang digunakan untuk DNA KHV dan A. hydrophila adalah pada suhu $55^{\circ} \mathrm{C}$ (Gambar 5). Gambar 5 menunjukkan visualisasi DNA KHV A. hydrophila dari sampel yang terinfeksi ko-infeksi KHV dan bakteri A. hydrophila, pita DNA menunjukkan positif virus KHV dan bakteri A. hydrophila pada ukuran 290 bp dan 417 bp. Hasil optimasi untuk amplifikasi DNA dengan menggunakan termalcycler dengan suhu dPCR sebagai berikut: pradenaturasi pada suhu $94^{\circ} \mathrm{C}$ selama dua menit, denaturasi pada suhu $95^{\circ} \mathrm{C}$ selama satu menit, annealing pada suhu, $55^{\circ} \mathrm{C}$ selama satu menit, dan extention $72^{\circ} \mathrm{C}$ selama satu menit, diikuti siklus amplifikasi 30 dan final extention pada suhu $72^{\circ} \mathrm{C}$ selama lima menit dengan komposisi master mix adalah untuk $25 \mu \mathrm{L}$ reaksi dengan master mix $12,5 \mu \mathrm{L}$; nuclease free water $6,5 \mu \mathrm{L}$; primer $10 \mathrm{pmol}$ untuk forward $1 \mu \mathrm{L}$, reverse $1 \mu \mathrm{L}$, dan template DNA masing-masing $2 \mu \mathrm{L}$.

Pada proses optimasi telah berhasil dilakukan amplifikasi KHV dan A. hydrophila secara simultan menggunakan duplex PCR di dalam satu campuran reaksi yang sama sehingga akan muncul dua pita pada satu lane. Pada tahap ini tidak ditemukan pita non-
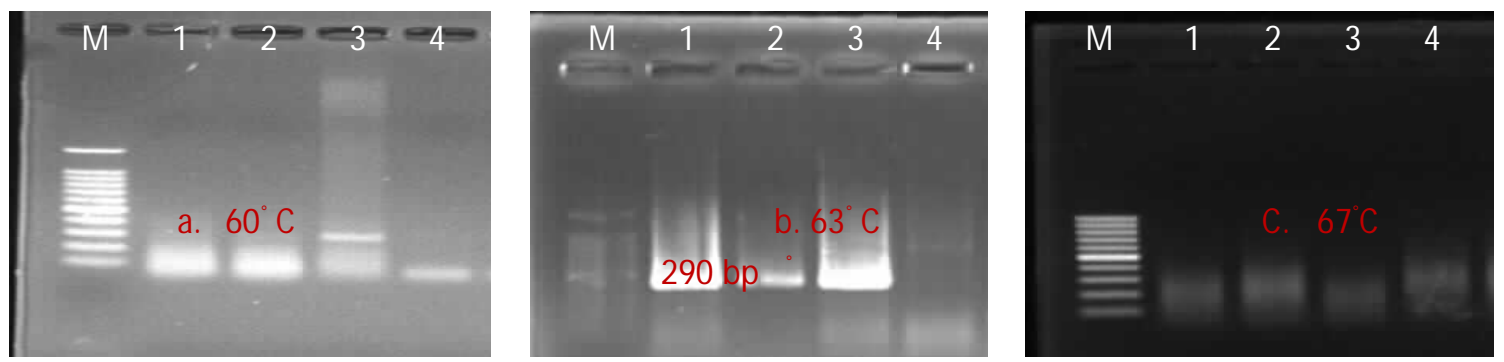

Gambar 4. Hasil deteksi duplex PCR KHV A. hydrophila pada suhu annealing (a) $60^{\circ} \mathrm{C}$, (b) $63^{\circ} \mathrm{C}$, dan (c) $67^{\circ} \mathrm{C}$. M: marker (100 bp), (1) sampel-1, (2) sampel-2, (3) kontrol positif pada $290 \mathrm{bp}$, $417 \mathrm{bp},(4)$ kontrol negatif (-).

Figure 4. Results of detection of duplex PCR KHV A. hydrophila at annealing temperature (a) $60^{\circ} \mathrm{C}$, (b) $63^{\circ} \mathrm{C}$, and (c) $67^{\circ} \mathrm{C}$. M: marker (100 bp), (1) sample-1, (2) sample-2, (3) positive control at 290 bp, $417 \mathrm{bp},(4)$ negative control (-).

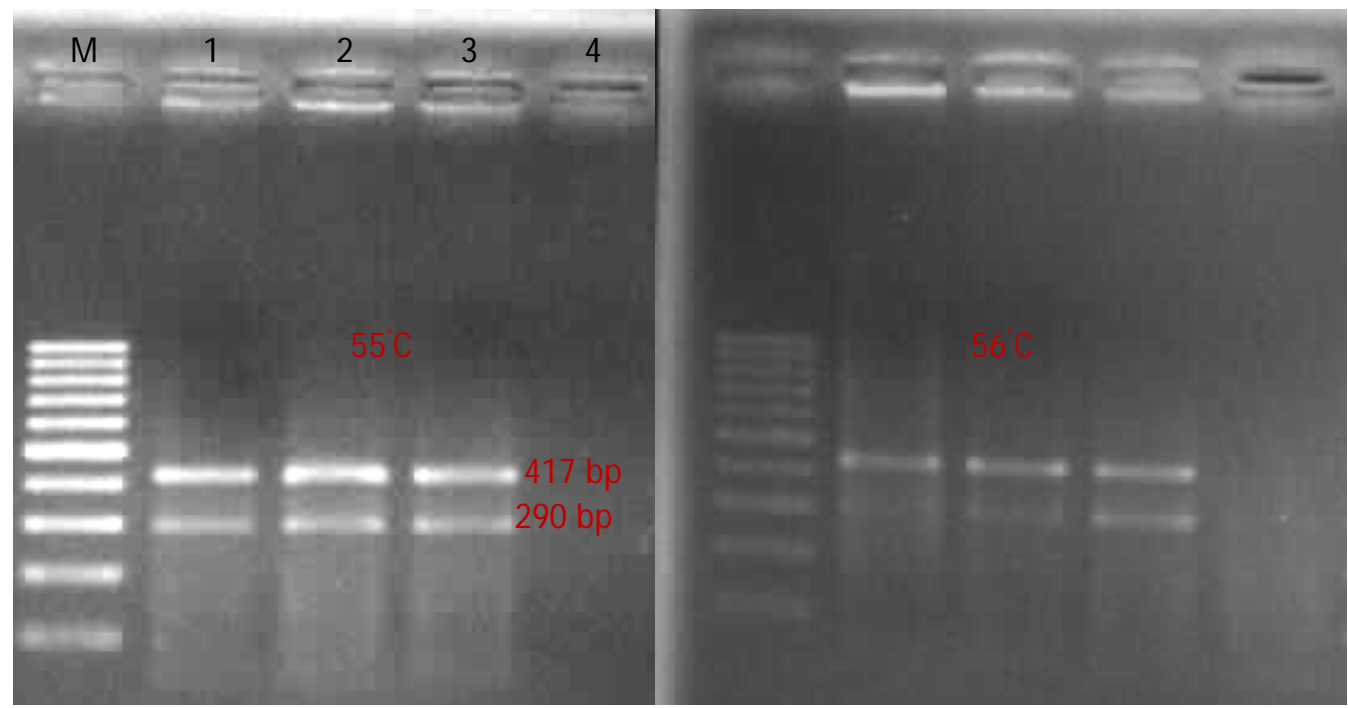

Gambar 5. Hasil deteksi dPCR KHV A. hydrophila pada suhu annealing $55^{\circ} \mathrm{C}$ dan $56^{\circ} \mathrm{C} . \mathrm{M}$ : marker (100 bp), (1) sampel-1, (2) sampel-2, dinyatakan positif (+ ) bila muncul pita PCR pada 290 bp, 417 bp, (3) kontrol positif pada 290 bp, 417 bp, (4) kontrol negatif (-), tidak menghasilkan pita.

Figure 5. Results of detection of $\mathrm{dPCR}$ of KHV A. hydrophila at annealing temperatures of $55^{\circ} \mathrm{C}$ and $56^{\circ} \mathrm{C}$. M: marker (100 bp), (1) sample-1, (2) sample-2, stated of positive $(+)$ if the PCR band appears at $290 \mathrm{bp}, 417 \mathrm{bp},(3)$ positive control at $290 \mathrm{bp}, 417$ bp, (4) negative control (-), does not result of band. 
spesifik yang berukuran kecil dan ukuran amplikon untuk masing-masing target sudah sesuai. Hasil ini disebabkan karena penurunan suhu annealing, kesesuaian konsentrasi primer, dan volume DNA template. Konsentrasi primer yang terlalu rendah atau yang terlalu tinggi dapat menyebabkan tidak terjadinya proses amplifikasi (Harini et al., 2008). Selain itu, faktor utama yang membedakan antara PCR single dan duplex adalah penambahan jumlah primer dalam satu reaksi, yaitu satu pasang primer untuk PCR single dan dua pasang primer untuk duplex PCR (Rizal et al., 2018). Metode deteksi PCR yang digunakan dalam pendeteksian keberadaan virus dan bakteri sangat berperan dalam melakukan pendeteksian dini dan cepat terhadap keberadaan lebih dari satu penyakit yang menyerang ikan mas. Deteksi ko-infeksi virus dan bakteri penyebab penyakit KHV-MAS pada pada ikan mas adalah dengan menggunakan PCR reaksi tunggal yang memerlukan waktu kurang lebih tiga jam dengan 40 siklus sedangkan dengan dPCR hanya membutuhkan waktu hanya dua jam dengan 30 siklus.

\section{Limit Deteksi Duplex KHV A. hydrophila}

Limit of detection (LOD) adalah nilai konsentrasi terendah deteksi yang dapat dilakukan. Nilai LOD ditentukan dengan melihat konsentrasi minimum DNA KHV dan A. hydrophila yang dapat tervisualisasi oleh elektroforesis dan menunjukkan band sepanjang 247 bp dan 290 bp. Hasil dari masing-masing konsentrasi DNA KHV A. hydrophila dengan mengencerkan konsentrasi DNA tersebut menjadi beberapa serial berikut; $100 \mathrm{ng} / \mathrm{mL}, 10 \mathrm{ng} / \mathrm{mL}, 1 \mathrm{ng} / \mathrm{mL}, 100 \mathrm{pg} / \mathrm{mL}, 10$ $\mathrm{pg} / \mathrm{mL}, 1 \mathrm{pg} / \mathrm{mL}, 100 \mathrm{fg} / \mathrm{mL}, 10 \mathrm{fg} / \mathrm{ml}, 1 \mathrm{fg} / \mathrm{mL}$, dan 100 $\mathrm{Ag} / \mathrm{mL}$. Sebagai target dPCR dalam menentukan batas deteksi dari pengujian yang akan dilakukan (Gambar 6).
Gambar 6 merupakan hasil visualisasi PCR dengan konsentrasi $100 \mathrm{ng} / \mathrm{mL}$ sampai $100 \mathrm{Ag} / \mathrm{mL}$, menunjukkan bahwa band atau pita hasil amplifikasi dPCR yang masih terlihat tebal dan jelas terdeteksi pada konsentrasi $1 \mathrm{pg} / \mathrm{mL}$.

\section{KESIMPULAN}

Ko-infeksi oleh KHV dan A. hydrophila penyebab penyakit KHV-MAS pada ikan mas dapat dideteksi simultan melalui pengujian menggunakan PCR dengan suhu optimasi pradenaturasi pada suhu $94^{\circ} \mathrm{C}$ selama dua menit, denaturasi pada suhu $95^{\circ} \mathrm{C}$ selama satu menit, annealing pada suhu, $55^{\circ} \mathrm{C}$ selama satu menit, dan $72^{\circ} \mathrm{C}$ selama satu menit, diikuti siklus amplifikasi 30 dan final extention pada suhu $72^{\circ} \mathrm{C}$ selama lima menit dengan komposisi master mix adalah untuk $25 \mu \mathrm{L} /$ reaksi dengan master mix $12,5 \mu \mathrm{L}$; nuclease free water $6,5 \mu \mathrm{L}$; primer 10 pmol untuk forward $1 \mu \mathrm{L}$, reverse $1 \mu \mathrm{L}$ dan template DNA masing-masing $2 \mu \mathrm{L}$. Metode duplex PCR untuk deteksi simultan kedua patogen adalah salah satu metode yang dapat diaplikasikan untuk deteksi ko-infeksi virus dan bakteri dalam satu reaksi PCR.

\section{UCAPAN TERIMA KASIH}

Penelitian dibiayai oleh Anggaran Pendapatan Biaya Negara (APBN) 2016. Penulis ucapkan terima kasih kepada Instalasi Riset Pengendalian Penyakit Ikan (IRP2I), Depok, Balai Riset Perikanan Budidaya Air Tawar dan Penyuluhan Perikanan (BRPBATPP), Bogor. Penulis juga mengucapkan terima kasih pada Muslikha, Ainin M., Ahmad Wahyudi, dan Johan Afandi yang telah membantu dalam penelitian ini.

\section{DAFTAR ACUAN}

Belák, S., Thorén, P., LeBlanc, N., \& Viljoen, G. (2009). Advances in viral disease diagnostic and molecu-

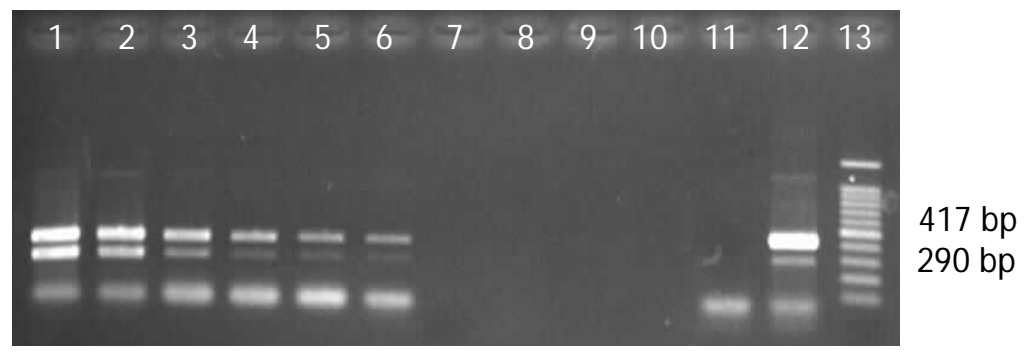

Gambar 6. Visualisasi DNA konsentrasi; (1) $100 \mathrm{ng} / \mathrm{mL}$, (2) $10 \mathrm{ng} / \mathrm{mL}$, (3) $1 \mathrm{ng} / \mathrm{mL}$, (4) 100 $\mathrm{pg} / \mathrm{mL}$, (5) $10 \mathrm{pg} / \mathrm{mL}$, (6) $1 \mathrm{pg} / \mathrm{mL}$, (7) $100 \mathrm{fg} / \mathrm{mL}$, (8) $10 \mathrm{fg} / \mathrm{mL}$, (9) $1 \mathrm{fg} / \mathrm{mL}$, (10) $100 \mathrm{Ag} / \mathrm{mL}$, (11) kontrol negatif, (12) kontrol positif, (13) M; Marker $100 \mathrm{Bp}$.

Figure 6. Visualization of DNA concentration; (1) $100 \mathrm{ng} / \mathrm{mL}$, (2) $10 \mathrm{ng} / \mathrm{mL}$, (3) $1 \mathrm{ng} / \mathrm{mL}$, (4) $100 \mathrm{pg} / \mathrm{mL}$, (5) $10 \mathrm{pg} / \mathrm{mL}$, (6) $1 \mathrm{pg} / \mathrm{mL}$, (7) $100 \mathrm{fg} / \mathrm{mL}$, (8) $10 \mathrm{fg} / \mathrm{mL}$, (9) $1 \mathrm{fg} / \mathrm{mL}$, (10) $100 \mathrm{Ag} / \mathrm{mL}$. (11) negative control, (12) positive control. (13) M; Marker $100 \mathrm{Bp}$. 
lar epidemiological technologies. Expert Review of M olecular Diagnostics, 9(4), 367-381.

Dooley, J., Lallier, R., Shaw, D.H., \& Trust, T.J. (1985). Electrophoretic and immunochemical analyses of the lipopoly saccharides from various strains of Aeromonas hydrophila. J. Bacteriol., 164(1), 263-9.

Gilad, O., Yun, S., Andree, K.B., Adkison, M.A., Way, K., Willits, N.H., Bercovier, H., \& Hedrick, R.P. (2003): Molecular comparison of isolates of an emerging fish pathogen, the koi herpesvirus, and the effect of water temperature on mortality of experimentally infected koi. J. Gen. Virol., 84, 2661-2668.

Harini, S.S., Leelombik, M., Kameshwari, M.N.S., \& Sathyanarayana, N. (2008). Optimization of DNA isolation and PCR-RAPD methods for molecular analysis of urginea indica Kunth. International Journal of Integrative Biology, 2, 138-144.

Hedrick, R.P., Gilad, O., Yun, S., Spangenberg, J.V., Marty, G.D., Nordhausen, R.W., Kebus, M.J., Bercovier, H., \& Eldar, A. (2000). A herpesvirus associated with mass mortality of juvenile and adult koi, a strain of common carp. Journal of Aquaticanimal Health, 12, 44-57.

Office International des Epizooties (OIE). (2016). Koi herpesvirus disease. 2 Maret 2016; $17 \mathrm{hlm}$. http:/ /www.oied.int, diunduh 4 Agustus 2016.

Nam, I.Y. \& Joh, K. (2007). Rapid detection of virulence factor of Aeromonas isolate from a trout farm by hexaplex-PCR. Departements of Bioscience and Biotechnology, Hankuk University of Foreign Studies, Young-In, Republic of Korea. The Jurnal of Microbiology, 4(45), 297-304.

Pikarsky, E. (2004). Pathogenesis of acute viral disease induced in fish by carp interstitial nephritis and gill necrosis virus. J. Virol., 78, 9544-9551.
Perelberg, A., Smirnov, M., Hutoran, M., Diamant, A., Bejerano, Y., \& Kotler, M. (2003). Epidemiological description of a new viral disease afflicting cultured Cyprinus carpio in Israel. The Israeli Journal of Aquaculture, 55(1), 5-12.

Rizal, A.A., Risa, T., April, H.W., \& Dyah, H.S. (2018). Deteksi parasit darah pada sapi perah berdasarkan analisis PCR Duplex. Acta Vet. Indonesian, 6(2), 48-55.

Ronen, A., Perelberg, A., Abramowitz, J., Hutoran, M., Tinman, S., Bejerano, I., Mand, S., \& Kotler, M. (2003). Efficient vaccine against the virus causing a lethal disease in cultured Cyprinus carpio. Vaccine, 21, 4677-4684.

Sambrook, J. \& Russel, D.W. (2001). Molecular cloning; A laboratory manual. 3rd Ed. New York: Cold Spring Harbor Laboratory Press, xxvii, Vol. 3.

Thanananta, N. \& Thanananta, T. (2008). Detection of $E$. coli in water using duplex polymerase chain reaction technique. Thai Journal of Genetics, 1(2), 109-113.

Yasmon, A., Yusmania, Karuniawati, A., \& Bela, B. (2010). Simultaneous detection of Legionella species and Legionella pneumophila by duplex PCR (dPCR) assay in cooling tower water samples from Jakarta, Indonesia. M ed. J. Indones., 19(4), 223-227.

Ye, Y.W., Fan, T.F., Li, H., Lu, J.F., Jiang, H., \& Hu, W. (2013). Characterization of Aeromonas hydrophila from hemorrhagic diseased freshwater fishes in Anhui Province, China. Int. Food Res. J., 20, 1449-52.

Yuasa, K., Motohiko, S., Jun, K., Takafumi, I., \& Takaji, I. (2005). Improvement of a PCR method with the Sph I-5. Primer set for the detection of koi herpesvirus (KHV). Fish Pathology, 40(1), 37-39. 